\title{
B Corp versus ISO 9001 and 14001 certifications: Aligned, or alternative paths, towards sustainable development?
}

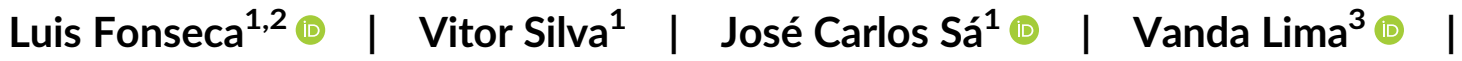 \\ Gilberto Santos ${ }^{4}$ (i) | Rui Silva ${ }^{5}$
}

\begin{abstract}
${ }^{1}$ School of Engineering, ISEP, Polytechnic of Porto, Porto, Portugal

${ }^{2}$ Mechanical and Industrial Engineering, INEGI - Institute of Science and Innovation in Mechanical and Industrial Engineering, Polytechnic of Porto, Porto, Portugal

${ }^{3}$ CIICESI, ESTG, Politécnico do Porto, Porto, Portugal

${ }^{4}$ Design School, Polytechnic Institute Cavado Ave, Barcelos, Portugal

${ }^{5}$ Engineering and Technology Faculty/ COMEGI, Universidade Lusíada, Norte, Portugal

Correspondence

Gilberto Santos, Design School, Polytechnic Institute Cavado Ave, Barcelos, Portugal.

Email: gsantos@ipca.pt

Funding information

FCT-Fundação para a Ciência e Tecnologia,

Grant/Award Number: UIDB/04728/2020
\end{abstract}

\begin{abstract}
Corporate social responsibility (CSR) emerged to deliver sustainable economic, environmental, and social value to organization's extended stakeholders and society in general. This study investigates the similarities, differences, and relationships between B Corp, ISO 9001, and ISO 14001 certifications and is supported by a mixed research methodology and a sample of 701 B Corp companies certified between January 2020 and March 2021. The results indicate that ISO 14001 and ISO 9001 certified B Corp companies have statistically higher scores for the Environment dimension but are inconclusive, or even contradictory, for the other BIA (B Impact Assessment) dimensions. Differences in size, activity sector and geographical location are discussed. It is shown that both B Corp, ISO 9001 and 14001 certified companies, guided by different missions and business models, contribute, at different levels, towards CSR and sustainable development goals.
\end{abstract}

KEYWORDS

B impact assessment, certified B Corp, corporate social responsibility, ISO 14001, ISO 9001 , stakeholder engagement, sustainable development, third-party certification

\section{1 | INTRODUCTION}

The relevance of sustainable development (SD) is recurrently emphasized at the highest level in the United Nations, lately reinforced by the 2030 Agenda for Sustainable Development (United Nations, 2015), and clearly addressed through the key sustainable development goals (SDGs), measuring the progress towards SD. Companies are key actors in promoting SD and the concept of corporate social responsibility (CSR) has emerged in reply to the global sustainability challenge. Given the generic nature of the definition of CSR, operationalization is not straightforward and thus several models and standards have been proposed to promote CSR.

The importance of CSR has led other institutions to launch different directives in support to CSR, such as B Lab certifications. B Corp certificates are issued by $B$ Lab, an independent non-profit US-based entity, to for-profit companies that integrate societal and environmental goals in their business model and strategy (B Lab Certification, 2021). To become B Corp Certified, companies must complete a B Impact Assessment (BIA) that measures and manages the company positive impact on its workers, community, customers, and environment, both at the operational as well as at the business model level and achieve a minimum score level. Presently, there are over 3000 B Corp certified organizations, with approximately $50 \%$ being based in the United States and Canada. At a more global level, the International Organization for Standardization (ISO), through ISO 9001 and ISO 14001, is regarded as the leading Quality Management and Environmental Management International Standard, with more than 880,000 (ISO 9001) and 310,000 (ISO 14001) certificates worldwide (ISO, 2020), across a wide range of countries and sectors.

Considering the relevance of ISO 9001 and ISO 14001 certification and the emergent nature of B Corp certification, this study addresses the relationships between the proprietary B Corp and the ISO 9001 and ISO 14001 standards. This paper unveils the impact of the B-Corp certification (governance, workers, community, environment, and customers) and its relationship to ISO 9001 or ISO 14001 certified companies in terms of the observed impact. To the best of our knowledge, this is a novel research dimension, following the 
suggestion of academics concerning the need for more research addressing B Corp certification.

The following section presents the literature review, followed by the materials and methods (qualitative and quantitative) and the research questions that support this research. Section 4 provides the results of the study. In the final sections, a summary of the results is presented and discussed.

\section{LITERATURE REVIEW}

The United Nations Commission on Environment and Development (Brundtland Commission) first defined SD as "the development that meets the needs of the present without compromising the ability of future generations to meet their own needs," to address humanity's aspirations to a better life within the limitations imposed by nature (United Nations Brundtland Report, 1987). A 10 years later, the United Nations Agenda for Development (United Nations, 1997) reaffirmed that "economic and social development, and environmental protection, are interdependent and mutually reinforcing components of SD". In 2012 the United Nations Conference on Sustainable Development in Rio (United Nations, 2012) called for SDGs emphasizing the central role of equality and sustainability in the global development effort. Further, in 2015, the General Assembly of the United Nations (UN) formally adopted "The 2030 Agenda for Sustainable Development" (United Nations, 2015) and agreed upon the SDGs. The SDGs can indicate and measure the progress towards SD and represent a shared expression of global stakeholder needs, balancing economic, social, and environmental development (Fonseca et al., 2020).

Companies are key actors in promoting SD (Diez-Busto et al., 2021). There is considerable research into understanding how business works and stakeholders' value is created. Many definitions of business models have been proposed (Ritter \& Lettl, 2018), with many authors proposing business models based on the essential business elements to create, distribute, and capture value (Fonseca, 2021). Nevertheless, research on how the SDGs can support business value creation (Adams, 2017) and how the private sector supports the SDGs is scarce (Fonseca \& Carvalho, 2019a; Izzo et al., 2020; Van Zanten \& Van Tulder, 2018).

\section{1 | Sustainability and CSR}

At the corporate level, the concept of CSR has emerged as an answer to the global sustainability challenge. CSR is an umbrella construct developed by society that encompasses numerous concepts and ideas such as corporate responsibility, business ethics, corporate citizenship, and SD (Fonseca, 2015a). Many authors have contributed to the CSR debate. Early in the 60's Eells (1958) highlighted the role of philanthropy with regards to CSR. For Johnson (1971) a socially responsible company should take into consideration the needs of the different stakeholders (employees, suppliers, and shareholders) while pursuing economic well-being. For Davis (1973), social responsibility encompasses the attainment of company goals along with, and inline with, the benefits for society. Zenisek (1979) also considered that social responsibility comprehends the behavior of a company and the subsequent actions to meet societal expectations. Carroll (1991, 1999) systematized the concept of CSR and proposed a model for the conceptualization of CSR based on four categories of business social responsibilities placed as a pyramidal model, from bottom to top: (a) economic responsibilities; (b) legal responsibilities; (c) ethical responsibilities; and (d) discretionary responsibilities. The United Nations Commission on Environment and Development (United Nations, 1997), and the 2012 United Nations Conference on Sustainable Development in Rio (United Nations, 2012), led to changes in the concept of social responsibility, with the incorporation of environmental aspects (Dobers \& Springett, 2010). The business community adopted the concepts of sustainability and SD (Carroll \& Shabana, 2010), encompassing the economic, environmental, and social dimensions. The latest understanding on CSR focuses more on corporate business models and the concept of SD on key changes in the global environment (Dobers \& Springett, 2010). The International Organization for Standardization, ISO 26000:2010 International Standard, Guidance on social responsibility (ISO, 2010), advanced the following definition (without "Corporate" to signal that social responsibility is applicable to all types of organizations):

1. "Social responsibility, is the responsibility of an organization for the impacts of its decisions and activities on society and the environment, through transparent and ethical behavior that: contributes to SD, including health and the welfare of society; takes into account the expectations of stakeholders; is in compliance with applicable law and consistent with international norms of behavior; and is integrated throughout the organization and practiced in its relationships" (ISO 26000:2010).

However, there are many definitions of CSR and Dahlsrud (2008) analyzed, through content analysis, provided 37 CSR definitions, concluding that most definitions encompass an economic, environmental, social, stakeholder and voluntarism dimension. Hence, both SD and social responsibility aim to, simultaneously, search for profitable economic development with social progress and equity while respecting the natural environment. Therefore, generating value for shareholders, customers, workers, partners, and society in general, with sustainability more focused at the institutional level and CSR at the organization level (Fonseca \& Ferro, 2016).

On a theoretical level, CSR is supported by Stakeholder Theory (Carroll \& Schwartz, 2003; Freeman, 1984; Freeman \& Dmytriyev, 2017; McWilliams \& Siegel, 2001). Stakeholder Theory emphasizes the relevance of a firm's relationships with its critical stakeholders stating that it will lead to better performance, as the integration of business and societal considerations creates stakeholder value. By creating social value, organizations can make positive and enduring impacts on society (e.g., new jobs creation, pollution reduction and support to vulnerable people or social and community projects) and can increase goodwill and trust, and promote access to 
resources and capabilities it needs to be sustainable (Fonseca, 2015a; Mcwilliams \& Siegel, 2011). Moreover, the resource-based view (RBV) Theory can also support CSR given that it states that an organization should identify and use valuable, rare, difficult to copy, and nonsubstitutable resources to gain competitive advantages and abnormal profits (Barney, 1991, 2001). The application of CSR can generate these resources and support the integration with stakeholders (an inimitable resource) in response to their demands. Further, Institutional Theory Adoption, that denotes the adoption of models from successful organizations, can also explain the spread of certification. Hence, organizations converge and become similar, because of societal influence and the search for organizational legitimacy (DiMaggio \& Powell, 2000; Meyer \& Rowan, 1977). Therefore, companies are more likely to be certified if successful companies in their activity sector or geographical area have done so (Rankin \& Matthews, 2020).

The relationship between economic and social performance leads often to the question-Can ethical behaviors (normative orientation) result in significant competitive advantage (instrumental orientation)? Most authors (e.g., Berrone et al., 2007; Fonseca et al., 2016; Margolis \& Walsh, 2003; Mattingly, 2017; Orlitzky et al., 2003; Trudel \& Cotte, 2009), have argued that companies that implement social responsibility policies and satisfy the expectations of their stakeholders have higher economic benefits than competitors and achieve positive differentiation. However, other researchers have found a neutral or even negative relationship between social and economic performance (Aupperle et al., 1985; Mcguire et al., 1988). Considering the generic nature and scope of CSR definitions, their operationalization is not straightforward (Lankoski, 2016; Poddar et al., 2019). Hence, further research is needed to address CSR holistic models and enduring business value creation (Silvestre \& Fonseca, 2020) and better understand the nature of those relationships, CSR performance, and its contribution to the SDGs.

\section{2 | B Corp certification}

B Corp certificates are issued by B Lab, an independent non-profit US-based institution founded in 2006. B Corps are for-profit companies that integrate societal and environmental goals in their business model and strategies (B Lab Certification, 2021). Presently, Regional B Labs currently operate in approximately 50 countries, with over 3500 Certified B Corporations in more than 70 countries (B Corporation, 2021a). According to Kim (2021), as of February 2020, more than 4000 companies were B Corp certified, with 3100 holding a valid certification, which implicates an overall $23.7 \%$ decertification or attrition rate (961/4061). There were B Corp certified companies in 72 countries, with the United States and Canada representing approximately $50 \%$ of the total number of valid certificates, followed by Europe (18.6\%) and South America (15.6\%). B Corp Certification is predominant in smaller companies, with more than half of B Corp certified companies having less than 10 employees and more than $80 \%$ having less than 50 employees (Kim, 2021).
Companies that want to apply for B Corp Certification must start by completing a B Impact Assessment (BIA) to measure and manage the company positive impact on its workers, community, customers, and environment, both at the operational and business model level. The BIA is conducted through a confidential online platform and covers the following aspects (B Lab Certification, 2021; B Lab Certification Requirements, 2021; The Complete Guide to B Corp Certification, 2020):

1. Governance: adoption of a social or environmental mission, ethics, accountability, and transparency; engagement with employees, board members, community, and customers; diversity of governing bodies.

2. Workers: compensation, benefits, training, and ownership opportunities; work environment, communication, health and safety, career development and job flexibility; worker ownership and engagement.

3. Community: supplier relations, diversity, and involvement in the local community, for example, community service and charitable giving; whether a company's product or service is designed to solve a social issue.

4. Environment: environmental management, products, and services; emissions, water, waste; resource preservation; energy efficiency; suppliers and transportation; impacts on climate, water, land, and life; whether a company's products or services are designed to solve an environmental issue.

5. Customers: company impact on its customers, namely whether its products or services promote public benefit and if those products/ services are targeted towards serving underserved populations; whether a company's product or service is designed to solve a social or environmental issue.

Main company characteristics (size, sector, and market) determine the questions (approximately 200 in total) of a company's B Impact Assessment. The content of the BIA is overseen by B Lab's independent Standards Advisory Council, and if the minimum threshold BIA score of 80 on 200 is reached, B Lab perform an audit procedure to check the BIA score. If the audit result confirms the score, a company can be granted B Corp certification, which requires signing an agreement and paying a yearly fee (based on the annual sales volume) to $B$ Lab. Additionally, B Corps are legally required to consider their impact on all stakeholders, adopting suitable transparency and accountability requirements. The certification is valid for 3 years, after which the company needs to retake the BIA. Furthermore, B Lab conducts randomly chosen in-depth site reviews with $10 \%$ of its certified B Corps on a yearly basis (B Lab Certification Requirements, 2021).

Kirst et al. (2021) carried out a systematic literature review (SLR), encompassing 65 papers on the potential contributions of CSR and SD of benefit corporations (BCs) and certified benefit corporations (B Corps) (Gazzola et al., 2019). They conclude that more recent research emphasizes $B$ Corp studies through various lenses, such as CSR and sustainable business models. In another SLR on the B Corp movement, encompassing 50 scientific articles published until 2020, 
Diez-Busto et al. (2021) identified some of companies' motivations to be B Corp certified and the economic and social effects of certification to be the primary research topics. The results indicate some inconsistencies between different studies, suggesting the need to harmonize research criteria. Some research posits that B Corp certified companies improve productivity after certification (Romi et al., 2018). Conversely, other studies conclude that productivity does not improve when compared to uncertified competitors (Chen \& Kelly, 2015). Furthermore, there is also inconsistencies between sales growth after B Corp certification, with authors such as Chen and Kelly (2015) and Romi et al. (2018) identifying sales growth, while Gamble et al. (2019) reporting a slowdown in revenue and in business growth.

Research also shows that among the motivations to pursue $B$ Corp certification there is also a need to address stakeholders' interest in positive differentiation from other traditional companies (Kim et al., 2016). According to Paelman et al. (2020), the motivations match those found in the literature concerning ISO 14001Environmental Management Standards. Namely, improving the environmental performance, complying with environmental legislation, decreasing the risk level of penalties and litigation, and enhancing stakeholder satisfaction and employee morale (Fonseca \& Domingues, 2018). B Corp BIA covers the three SD dimensions (economic, environmental, and social), addresses all stakeholders, and provides a BIA report with scores in several dimensions. Other certifications such as ISO 14001 are focused on the environment; the IRIS+ system from the Global Impact Investing Network targets mainly investors; and the Global Reporting Initiative (GRI) is more focused on standardized reporting of companies' non-financial information. Nevertheless, some research (Villela et al., 2021) reports that some B Corp certified companies focused more on improving their external reputation with investors, clients and consumers than improving their internal processes and addressing complex problems of corporate governance.

\section{3 | ISO 9001 and ISO 14001 certification}

Adopting voluntary management standards (MS) as a regulatory mechanism to respond to stakeholder concerns was emphasized by the growth of global supply chains (Büthe \& Mattli, 2011): ISO 9001 Quality Management System-Requirements (ISO, 2015a) and ISO 14001:2015 Environmental Management System: Requirements with Guidance for Use (ISO, 2015b). These MSs can be audited and certified by independent external certification bodies (CBs) that, by performing a third-party audit, assess whether the applicable MS complies with the international reference and achieves the intended results (Fonseca et al., 2017). The widest adopted ISO International Management System Standards are ISO 9001 with 883521 certificates and ISO 14001 with 312580 certificates worldwide (ISO, 2020). ISO edited the ISO 9001 series in 1987 and in this standard organizations that adopted and certified their Quality Management Systems (QMSs) accordingly were mainly focused on implementing a documented QMS to support their efforts for globalization (Yahya \& Goh, 2001). In the following years, organizations started to emphasize their efforts in process performance and customer satisfaction improvement enhancing the QMS contribute to the organization's success (Chatzoglou et al., 2015; Fonseca et al., 2019; Poksinska et al., 2006; Prajogo, 2011; Singh, 2008). Academic research posits that ISO 9001 certification generates both internal and external benefits such as improved product quality and process performance (Costa et al., 2019; Sá et al., 2020; Santos et al., 2021), cost reductions, and higher quality awareness, leading to improved customer satisfaction, strong market image, and a more favorable competitive position (Araújo et al., 2019; Boiral, 2012; Bravi et al., 2019; Fonseca et al., 2017; Sfreddo et al., 2021; Tarí et al., 2012) to create value (Santos et al., 2019; Santos et al., 2019). Academic research emphasizes the contribution of QM for SD, namely, the support of QMS for SD initiatives and Environmental Management Systems' (EMS) implementation (Siva et al., 2016). ISO supports this point of view, according to section 0.1 of ISO 9001:2015 (ISO, 2015a) "The adoption of a quality management system is a strategic decision for an organization that can help to improve its overall performance and provide a sound basis for sustainable development initiatives."

The success of ISO 9001 contributed to the diffusion of ISO 14001 adoption and certification (Fonseca et al., 2017). ISO 14001 EMS assumes that better environmental performance can be reached when environmental aspects are systematically identified and managed through pollution prevention, improved environmental performance and compliance with applicable laws, giving a significant contribution to Sustainability (Fonseca, 2015b). Among the drivers of ISO 14001 certification are the compliance with specific environmental legislation, improvement of environmental awareness and performance, reduction in waste, emissions, and resource consumption, enhancement of corporate image, risk minimization and responsiveness to stakeholder's expectations (Fonseca \& Domingues, 2018; Zeng et al., 2005). The reported benefits of ISO 14001 concern improved EMS and process efficiencies leading to cost reductions and minimization of environmental impacts and associated risks, that in turn, contribute to increased organizational performance (Fonseca \& Domingues, 2018; Murmura et al., 2018) and, in the long run, foster profitability and market benefits (Lee et al., 2017). Moreover, Ma et al. (2021), in research with Chinese manufacturing companies, concluded that green public procurement (GPP) market pressure is positively associated with environmental certification practice, with top management support partially mediating this relationship. ISO 14001 can also support organizations appropriate environmental indicators, which is relevant to demonstrate their support and transparency CSR and SD (Murillo-Avalos et al., 2021).

ISO $9001: 2015$ and ISO 14001:2015 share common concepts, core text, and high-level structure to facilitate the harmonization and unity of the Quality and Environmental Management System. Academic research highlights that the two MSs (QMS and EMS) match SD's economic and environmental dimension and are mutually reinforced (Barbosa et al., 2018; Carvalho et al., 2020; Gianni et al., 2017; Nunhes \& Oliveira, 2018; Santos et al., 2011), hence, 
promoting a successful and balanced SD (Bernardo et al., 2015; Bravi et al., 2020; Rebelo et al., 2015; Santos et al., 2014; Santos et al., 2018; Talapatra et al., 2019).

\section{4 | B Corp versus ISO 9001 and ISO 14001 certification}

B Corp is a proprietary certification scheme from B Lab, an independent US-based non-profit organization, and is more prominent within smaller companies (Kim, 2021). ISO 9001 and ISO 14001 are International Management Systems Standards issued by the International Organization of Standardization (ISO). ISO 9001 and ISO 14001 follow ISO rules concerning the preparation, approval, and revision of ISO International Standards, ensuring a balanced multi-country and multi-stakeholder dimension (Fonseca \& Carvalho, 2019b). Moreover, ISO 9001 and ISO 14001 certification by accredited certification bodies is subject to the surveillance of National Accreditation Bodies under the International Accreditation Forum global supervision.

Geographically, China accounts for $31.7 \%$ of the total ISO 9001 certificates and $43.2 \%$ of the ISO 14001 certificates, while the United States and Canada account for just $2.9 \%$ and $1.4 \%$ of the total ISO 9001 and ISO 14001 certificates. This is in sharp contrast with the geographical distribution of B Corp certificates, where the United States and Canada account for $49 \%$ of total B Corp certificates and Asia in total represents just 3.2\% of total certificates (Kim, 2021).

To compare the requirements of B Corp versus ISO 9001 and ISO 14001, a content analysis was performed, and the summary results are presented below in Table 1:

In summary, there are strong links between the B Corp Environment dimension and ISO 14001:2015 and between the B Corp Customer dimension and ISO 9001:2015. In contrast, the weakest link appears to be between the B Corp community dimension and both ISO 9001 and ISO 14001. These two ISO standards do not specifically

TAB LE 1 B Corp versus ISO 9001:2015 and ISO 14001:2015 - correlated requirements

\begin{tabular}{ll} 
B Corp & ISO 9001:2015 requirements \\
\hline $\begin{array}{l}\text { Governance: adoption of a social or } \\
\text { environmental mission, ethics, }\end{array}$ & 4.1 Understanding the organization and its \\
accountability, and transparency; & context; 4.2 Understanding the needs \\
engagement with employees, board & and expectations of interested parties. \\
members, community, and customers; & 5.1 Leadership and commitment; 5.2 \\
\hline
\end{tabular}

diversity of governing bodies.

Workers: compensation, benefits, training, and ownership opportunities; work environment, communication, health and safety, career development and job flexibility; worker ownership and engagement.

Community: supplier relations, diversity, and involvement in the local community, for example, community service and charitable giving; whether a company's product or service is designed to solve a social issue.

Environment: environmental management, products, and services; emissions, water, waste; resource preservation; energy efficiency; suppliers and transportation; impacts on climate, water, land, and life; whether a company's products or services are designed to solve an environmental issue.

Customers: company impact on its customers, namely whether its products or services promote public

benefit and if those products/services are targeted towards serving underserved populations; whether a company's product or service is designed to solve a social or environmental issue.
4.1 Understanding the organization and its context; 4.2 Understanding the needs 4.3 Information for external providers.

7.1.4 Environment for the operation of processes; 8.4 Control of externally provided processes, products, and services (... evaluation, selection, monitoring of performance, and reevaluation of external providers); 8.5.5 Post-delivery activities; 9.1 Monitoring, measurement, analysis, and evaluation (... the performance of external providers)

5.1.2 Customer focus; 9.1 Monitoring, measurement, analysis, and evaluation (9.1.2 Customer satisfaction).

\section{ISO 14001:2015 requirements}

4.1 Understanding the organization and its context; 4.2 Understanding the needs and expectations of interested parties; 4.3 Determining the scope of the environmental management system.; 4.4 Environmental management system; 5.1 Leadership and commitment; 5.2 Environmental policy.

7.1.2 People; 7.1.4 Environment for the operation of processes; 7.2 Competence; 7.3 Awareness; 7.4 Communication.

7.2 Competence; 7.3 Awareness; 7.4 Communication (... of EMS)

\begin{abstract}
4.2 Understanding the needs and expectations of interested parties (Community and suppliers as interested parties).
\end{abstract}

5.2 Environmental policy; 6.1.2 Environmental aspects; 6.2 Environmental objectives and planning to achieve them; 8.1 Operational planning and control (...processes needed to meet EMS requirements); 9 Performance evaluation (... monitor EMS performance); 10. Improvement (EMS)

\subsection{Understanding the needs and expectations of interested parties (Customers as an interested party).}


address diversity and involvement with the local community (e.g., community service and charitable giving) or whether a company's product or service takes in consideration social issues.

The literature review and theoretical framework, as well as the provided comparison between B Corp, ISO 9001, and ISO 14001 correlated requirements, show alignment evidence that support further, and in-depth, analysis.

\section{3 | MATERIALS AND METHODS}

This research is supported by a mixed methods research approach. First, a literature review on the different constructs of CSR, B Corp certification, and ISO 9001 and ISO 14001 certification were performed through a systematic and reproducible procedure, following Littell, Corcoran, \& Pillai, 2008. Afterwards, an exploratory search for articles on Elsevier databases was conducted and grouped into several categories (CSR, B Corp, ISO 9001, ISO 14001), in addition to other sources of information such as B Corp and ISO websites and standards. The final stage of the review focused on content analysis (Berg, 2009) to identify relevant contributions to the present research and help define the research questions.

This research focuses on the similarities, differences, and relationships between B Corp, ISO 9001, and ISO 14001 certifications. It aims to assess if there are statistically significant differences for B Corp certified companies for BIA assessments scores between those that are ISO 14001 and ISO 9001 certified and those that are not. Hence, the following research questions are proposed:

RQ1. Are there statistical differences in the BIA assessments scores between those companies that are ISO 9001 certified and those that are not?

RQ2. Are there statistical differences in the BIA assessments scores between those companies that are ISO 14001 certified and those that are not?
After the formulation of the Research Questions and the content comparison of the requirements between B Corp versus ISO 9001 and ISO 14001, the data set of B Corps certified companies was obtained from the Directory of Certified B Corporation website (B Corporation, 2021a), yielding a total of 2262 certifications issued between January 2017 and March 2021 (not considering companies certified between 2007 and the end of 2016). As shown in Figure 1, North America, and Europe account for $69 \%$ of total B Corp certifications. The comparison of B Corp certification data between April 2021 and February 2020 (Kim, 2021), shows the following:

1. The total number of valid B. Corp certificates has grown from 3100 (February 2020) to 3500 (April 2021), a 13\% increase.

2. B Corp certification is growing outside the United States, namely in Europe. In February 2021, the United States in Canada represented $50 \%$ of the total B. Corp valid certificates. In the period between January 2017 and March 2021 it dropped to 37.7\%. Conversely, Europe accounted for just $18.6 \%$ of the valid certificates but represents $32 \%$ of the total certificates issued between January 2017 and March 2021.

Four Anglo Saxon countries-United States (30.1\%), United Kingdom (13.4\%), Australia (7.6\%) and Canada (7.6\%)-account for a total of $58.7 \%$ of the B Corp certifications issued between January 2017 and March 2021. B Corp certifications are present in 71 countries, and the top 10 countries account for $80 \%$ of the total number of certificates.

In 2019 B Corp introduce Version 6 of the B Impact Assessment, developed by B Lab and its Standards Advisory Council, aiming to make "BIA more consistent, more aligned, and more clearly articulated", BIA (2021). Hence, to ensure consistency of BIA assessments, the final data set was restricted to companies certified during 2020 and 2021, that were already evaluated with BIA Version 6. This yielded a final sample of 701 companies, with 583 certified in 2020 (83.2\%) and the remaining 118 (16.8\%) in 2021. The data set included

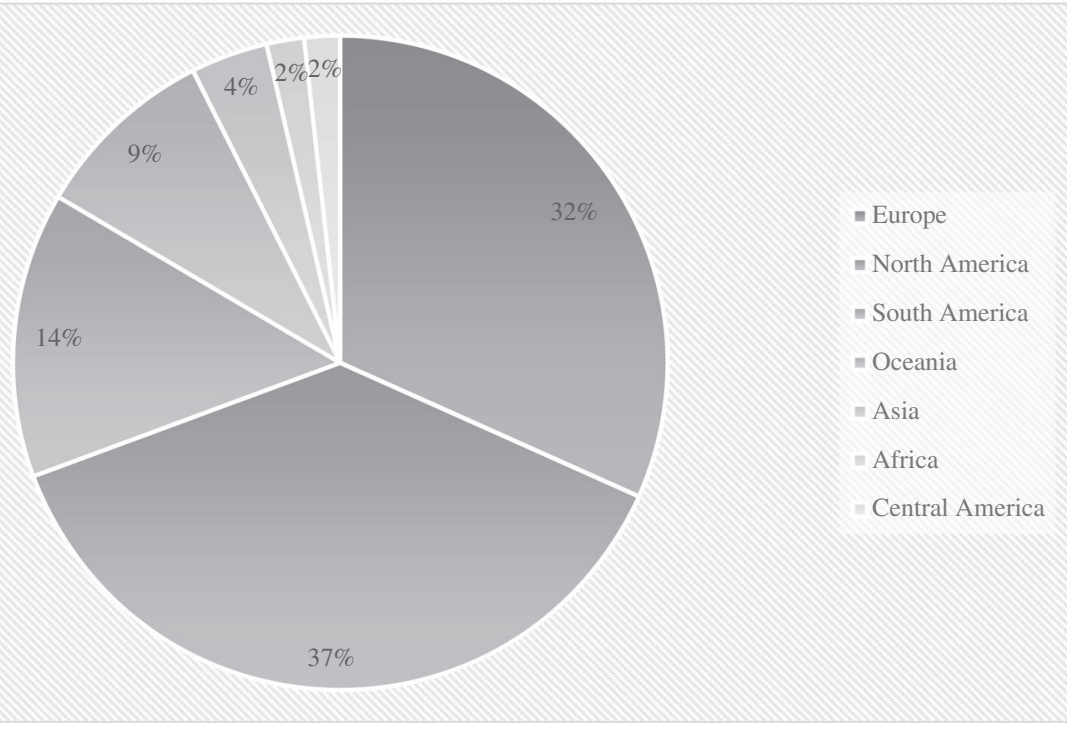

FIGURE 1 Number of B Corp certifications in 2020 and 2021 (April 2021) 
FIGURE 2 Number of B Corp certifications by industry sector in 2020 and 2021 (April 2021)

TABLE 2 Sector of activity of B Corp companies certified in 2020 and 2021 (April 2021)

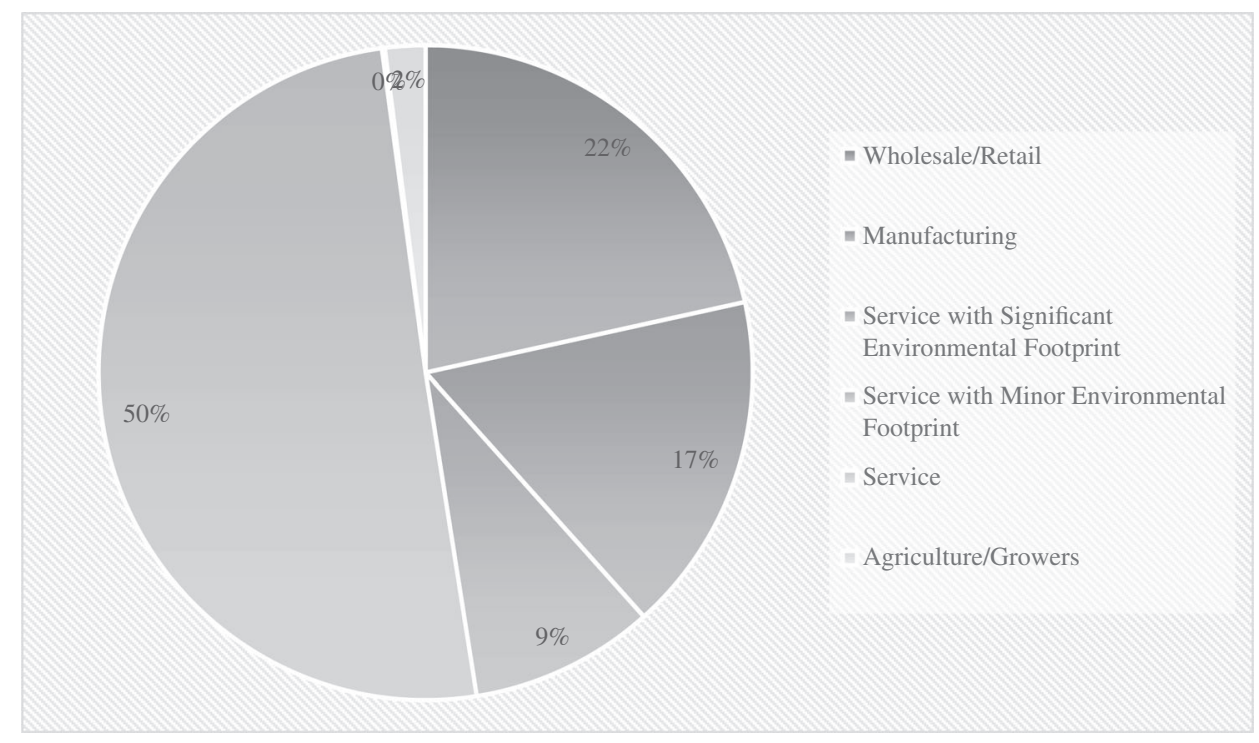

\begin{tabular}{|lccc|}
\hline Sector of activity & Frequency & Percent & $\begin{array}{l}\text { Cumulative } \\
\text { percent }\end{array}$ \\
\hline Wholesale/retail & 151 & 21.5 & 21.5 \\
\hline Manufacturing & 118 & 16.8 & 38.4 \\
\hline $\begin{array}{l}\text { Service with significant environmental } \\
\text { footprint }\end{array}$ & 64 & 9.1 & 47.5 \\
\hline Service with minor environmental footprint & 353 & 50.4 & 97.9 \\
\hline Service & 1 & 0.1 & 98.0 \\
\hline Agriculture/growers & 14 & 2.0 & 100.0 \\
\hline Total & 701 & 100.0 & \\
\hline
\end{tabular}

the certification data, size, sector and location of the company, and the BIA overall score and scores for the five dimensions. Next, an online search was conducted online to establish the status concerning ISO 9001 and ISO 1400 for those 701 companies. This process led to the identification of 37 valid ISO 9001 certifications (5.3\%) and 28 ISO 14001 certifications (4.0\%), resulting in an unbalanced sample between certified and non-certified ISO 9001/ISO 14001 companies. Additionally, not all the companies had full information on the five BIA dimensions.

Given the small sample size of ISO certified companies and the fact that the samples did not follow a normal distribution, non-parametric tests (Independent Samples Mann-Whitney $\mathrm{U}$ Test, significance level of 0.05) were applied to test the research questions with the support of IBM SPSS Statistics software (version 25).

\section{4 | RESULTS}

\section{$4.1 \quad$ Descriptive statistics}

As shown in Figure 2 and Table 2, half of the sampled companies are from the "Service with Minor Environmental Footprint" sector, followed by "Wholesale/Retail” (21.5\%) and “Manufacturing" (16.8\%).
Concerning the BIA assessments of the companies certified during 2020 and 2021 listed on the Directory of Certified B Corporation website (Directory of Certified B Corporation, 2021), the results presented in Table 3 highlight that Workers (26.4) and the Community (24.7) have the highest mean values, followed by Environment (17.1), Governance (13.5) and Customers (11.8).

\section{2 | B Corp versus ISO 9001}

The BIA assessments of the companies certified during 2020 and 2021 were gathered through the Directory of Certified B Corporation website; an online search obtained the status of those companies' ISO 9001 and ISO 14001 certifications. In relation to the BIA assessment depending on ISO 9001 certification (Table 4), the Community, Environment and Customers are the dimensions that present the greatest differences in mean values between the organizations that have ISO 9001 certification and those that do not have this certification.

Statistical correlations were performed through Mann-Whitney $U$ Tests (Table 5). For all tests, asymptotic significances are displayed and the significance level for null hypothesis rejection is 0.05 .

The above tests highlight the statistical differences on the BIA assessments scores between those companies that are ISO 9001 certified and those that are not (answer to RQ1). Organizations that are 


\begin{tabular}{|llllll|}
\hline Descriptive statistics & \multicolumn{7}{l}{} \\
\hline Dimensions & N & Minimum & Maximum & Mean & SD \\
\hline Governance & 701 & 4.10 & 23.70 & 13.2466 & 4.13311 \\
\hline Workers & 626 & 7.40 & 65.60 & 26.4249 & 7.62380 \\
\hline Community & 701 & 3.80 & 82.40 & 24.7061 & 12.58438 \\
\hline Environment & 701 & 0.50 & 66.70 & 17.0551 & 12.11321 \\
\hline Customers & 687 & 0.10 & 72.30 & 11.7780 & 13.14077 \\
\hline Total points & 701 & 80 & 166 & 90.18 & 11.846 \\
\hline Valid N (list wise) & 612 & & & & \\
\hline
\end{tabular}

TABLE 3 Descriptive statistics for BIA assessments

\begin{tabular}{|c|c|c|c|c|}
\hline Dimensions & $\begin{array}{l}\text { ISO } 9001 \\
\text { certification }\end{array}$ & $N$ & Mean & $S D$ \\
\hline \multirow[t]{2}{*}{ Governance } & Yes & 37 & 13.7919 & 4.25208 \\
\hline & No & 664 & 13.2163 & 4.12755 \\
\hline \multirow[t]{2}{*}{ Workers } & Yes & 35 & 26.9229 & 8.35654 \\
\hline & No & 591 & 26.3954 & 7.58489 \\
\hline \multirow[t]{2}{*}{ Community } & Yes & 37 & 19.5270 & 9.68251 \\
\hline & No & 664 & 24.9947 & 12.67019 \\
\hline \multirow[t]{2}{*}{ Environment } & Yes & 37 & 22.7405 & 14.57020 \\
\hline & No & 664 & 16.7383 & 11.89482 \\
\hline \multirow[t]{2}{*}{ Customers } & Yes & 34 & 7.8441 & 12.30147 \\
\hline & No & 653 & 11.9828 & 13.15965 \\
\hline \multirow[t]{2}{*}{ Total points } & Yes & 37 & 88.81 & 10.870 \\
\hline & No & 664 & 90.26 & 11.901 \\
\hline
\end{tabular}

TABLE 4 Descriptive statistics for BIA assessments depending on ISO 9001 certification

\begin{tabular}{|c|c|c|c|c|}
\hline \multirow[b]{2}{*}{ Dimensions } & \multicolumn{4}{|c|}{ Mann-Whitney $U$ tests } \\
\hline & $\begin{array}{l}\text { Total } \\
\mathrm{N}\end{array}$ & $\begin{array}{l}\text { Test } \\
\text { statistic }\end{array}$ & $\begin{array}{l}\text { Standardized } \\
\text { test statistic }\end{array}$ & Significance \\
\hline Governance & 701 & $13,298.000$ & 0.846 & 0.398 \\
\hline Workers & 626 & $10,217.000$ & -0.120 & 0.904 \\
\hline Community & 701 & 8574.000 & -3.095 & 0.002 \\
\hline Environment & 701 & $15,483.000$ & 2.668 & 0.008 \\
\hline Customers & 687 & 9510.000 & -1.410 & 0.158 \\
\hline Total Points & 701 & $11,373.500$ & -0.761 & 0.447 \\
\hline
\end{tabular}

TABLE 5 Test for BIA assessments depending on ISO 9001 certification
ISO 9001 certified differ from those that do not have this certification in terms of the observed impact on the dimensions of the B-Corp certification (governance, workers, community, environment, and customers). There are significant differences in the data distributions of the Community and Environment dimensions between organizations that have ISO 9001 certification and those that do not have this certification.

The above values indicate that, in the case of the Community dimension, the group with the best scores in the B-Corp certification is the one that does not have the ISO 9001 certification. On the other hand, in the case of the Environment dimension, the opposite situation is verified with the group with the best scores being the one with ISO 9001 certification.

\section{3 | B Corp versus ISO 14001}

In relation to the BIA assessment depending on the status of ISO 14001 certification obtained via the online search (Table 6), as expected, the greatest difference in mean values is found in the Environment dimension, with ISO 14001 certified organizations having the best performance. Community and Customers are also dimensions that present large differences between the mean values of the two groups of organizations.

Statistical correlations were performed through Mann-Whitney $\mathrm{U}$ Tests (Table 7). For all tests, asymptotic significances are displayed and the significance level for null hypothesis rejection is 0.05 . 
TABLE 6 Descriptive statistics for BIA assessments depending on ISO 14001 certification

\begin{tabular}{|llrlr|}
\hline Dimensions & ISO 14001 & & & \\
\hline Governance & certification & N & Mean & \multicolumn{1}{c|}{ SD } \\
& Yes & 28 & 13.4643 & 4.04440 \\
\hline Workers & No & 673 & 13.2376 & 4.13945 \\
\hline Community & Yes & 27 & 25.4407 & 8.72363 \\
& No & 599 & 26.4693 & 7.57576 \\
\hline Environment & Yes & 28 & 15.7500 & 5.08669 \\
\hline Customers & No & 673 & 25.0788 & 12.66667 \\
\hline Total points & No & 28 & 28.7036 & 13.35325 \\
& Yes & 673 & 16.5704 & 11.82330 \\
\hline & No & 26 & 5.6115 & 10.19381 \\
\hline & Yes & 661 & 12.0206 & 13.19050 \\
\hline
\end{tabular}

TABLE 7 Test for BIA assessments depending on ISO 14001 certification

\begin{tabular}{lllll}
\multicolumn{5}{c}{ Mann-Whitney U tests } \\
\cline { 2 - 5 } Dimensions & Total & $\begin{array}{l}\text { Test } \\
\text { statistic }\end{array}$ & $\begin{array}{l}\text { Standardized } \\
\text { test statistic }\end{array}$ & Significance \\
\hline Governance & 701 & 9527.500 & 0.100 & 0.920 \\
\hline Workers & 626 & 6942.500 & -1.245 & 0.213 \\
\hline Community & 701 & 4074.000 & -5.094 & 0.000 \\
\hline Environment & 701 & $14,422.500$ & 4.763 & 0.000 \\
\hline Customers & 687 & 5414.500 & -3.202 & 0.001 \\
\hline Total points & 701 & 8257.000 & -1.112 & 0.266 \\
\hline
\end{tabular}

The test results presented in Table 7 above emphasize the statistical differences of the BIA assessments scores between those ISO 14001 certified and those not (answer to RQ2). Organizations that are ISO 14001 certified differ from those that do not have this certification in terms of the observed impact on the dimensions of the B-Corp certification (governance, workers, community, environment, and customers). There are significant differences in the data distributions of the Community, Environment and Customers dimensions between organizations that have ISO 14001 certification and those that do not have this certification.

From the values obtained, we found that, in the case of the Community and Customers dimensions, the group with the best scores in the B-Corp certification is the one that does not have the ISO 14001 certification. On the other hand, in the case of the Environment dimension, the opposite situation is verified, as expected, with the group with the best scores being the one with ISO 14001 certification.

\section{5 | DISCUSSION}

The growing concern upon the global impact of activities on the environment has led to the promotion of SD which in turn gave rise to the concept of CSR as the answer of companies to the global sustainability challenge. SD and CSR share the common aim of profitable economic development with social progress, equity, and respect for the natural environment. Sustainability is more focused at the institutional level, and CSR at the organization level, both focusing on the generation of value for stakeholders and society in general. SD and CSR are both theoretically supported by the Stakeholder Theory (Freeman, 1984; McWilliams \& Siegel, 2001; Carrol \& Schwartz, 2003; Freeman \& Dmytriyev, 2017), RBV Theory (Barney, 1991, 2001) and Institutional Theory (DiMaggio \& Powell, 2000; Meyer \& Rowan, 1977). Given the generic nature of CSR definitions, several models and standards have been proposed to that end, including the B Corp, ISO 9001, or ISO 14001 certification.

As highlighted in the literature review section, both B Corp and ISO standards (ISO 9001 and ISO 14001) can support CSR and SD. Nevertheless, there are some remarkable differences:

1. B Corp is a proprietary scheme, while ISO 9001 and ISO 14001 are International Standards.

2. B Corp certification is managed by B Corp, and ISO 9001 and ISO 14001 are granted by independent third-party audit Certification Bodies.

3. There are more than 880,000 ISO 9001 and 310,000 ISO 14001 certificates worldwide, compared to approximately 3500 B Corp certificates. 
4. ISO 9001 and ISO 14001 certification are worldwide spread, with China being the country with more ISO 9001 (31.7\%) and ISO 14001 (43.2\%) certifications. Conversely, the United States and Canada account for just $2.9 \%$ and $1.4 \%$ of the total ISO 9001 and ISO 14001 certificates. However, with B Corp, the United States and Canada account for approximately $50 \%$ of the total certifications.

5. Services with a minor environmental footprint represent $50 \%$ of the total B Corp certificates issue in 2020 and 2021, while ISO 9001 and ISO 14001 are dominated by the manufacturing and global supply chain companies.

6. B Corp certification is more prominent with smaller companies (50\% of B Corp certified companies having less than 10 employees), while ISO 9001 and ISO 14001 certifications are more equally distributed by company size.

7. There are strong links between the B Corp Environment dimension and ISO 14001:2015 and between B Corp Customer dimension and ISO 9001:2015. However, links between B Corp communities' dimension and both ISO 9001 and ISO 14001 are weak. These two ISO standards do not specifically address diversity, involvement in the local community (e.g., community service and charity) or whether a company's product or service is designed to solve a social issue.

The descriptive statistics of the BIA assessments and the statistical testing shed additional light on the nature of the B Corp versus ISO 9001 and ISO 14001 relationships:

1. The BIA assessments statistics highlight that Workers (26.4) and the Community (24.7) have the highest mean values, followed by Environment (17.1), Governance (13.5) and Customers (11.8). Hence, there are variations on the several dimensions' mean values, and B Corp shows a stronger emphasis on Workers and the Community than on Customers. Conversely, ISO 9001 is primarily focused on Customers (and other relevant stakeholders) and ISO 14001 on the Environment.

2. The results indicate that for the Community dimension, the group with the best scores in the B Corp certification is the one that does not have the ISO 9001 certification. Conversely, the opposite situation occurs for the Environment dimension; the group with the best scores is the one with ISO 9001 certification. Organizations that are ISO 9001 certified differ from those that do not have this certification in terms of the observed impact on some of the dimensions of the B-Corp certification.

3. The results show that there are significant differences in the data distributions of the Community, Environment and Customers dimensions between organizations that have ISO 14001 certification and those that do not have this certification. In the case of the Community and Customers dimensions, the group with the best scores in the B-Corp certification is the one that does not have the ISO 14001 certification. Conversely, for the Environment dimension, as expected, the group with the best scores is the one with ISO 14001 certification.
The highest scores for Environment for the ISO 14001 and ISO 9001 certified B Corp companies are supported by the literature review and the B Corp versus ISO 9001 and ISO 14001 comparisons. ISO 14001 supports pollution prevention, improved environmental performance, and compliance with applicable laws (Fonseca, 2015a; Fonseca \& Domingues, 2018; Murmura et al., 2018). Moreover, in the long run, it improves profitability and market positioning (Lee et al., 2017), supporting green public procurement (Ma et al., 2021) and providing environmental indicators for organizations to demonstrate their support and transparency CSR and SD (Murillo-Avalos et al., 2021).

Within the Community dimension, the group with the best scores in the B Corp certification is the one corresponding to companies that do not have ISO 9001 certification or ISO 14001 certification. This might indicate that B Corps companies have different characteristics than ISO 9001 and ISO 14001 certified ones, such as smaller size, service sector prominence, main location, and common good mission orientation, when compared to ISO 9001 and ISO 14001 certified companies.

The tests show no statistically significative differences between the distribution of Customers data from organizations that are ISO 9001 certified and those that are not (RQ1). This is a result that was not expected from the literature review. Nevertheless, the customers' dimension shows the lowest mean of all the five BIA dimensions within the total sampled companies, suggesting that customer orientation is not particularly high for B Corps. In the case of ISO 14001 certified companies, the group with the best scores in the B Corp certification is the one that does not have the ISO 14001 certification (RQ2).

The Governance dimension also shows less favorable BIA mean values when compared to Workers, Community and Environment. ISO 9001 and ISO 14001 encompass leadership and establishes quality and environmental policies and their subsequent deployment and improvement, but not to the extent of the BIA assessment requirements. There are no statistically significative differences between the values of ISO 9001 and ISO 14001 certified and non-certified B Corps (Certified B Corp, 2020).

\section{6 | CONCLUSIONS}

This exploratory study indicates that B Corp versus ISO 9001 and 14001 certifications are driving companies in the same direction, towards SD and addressing CSR. Nevertheless, B Corp, ISO 9001 and 14001 certified companies seem to be guided by different missions and business models and contributing differently to the dimensions of CSR and SD. The result, as suggested by Gazella et al. (2019), support the idea that $\mathrm{B}$ Corps is a possible alternative to manage business and sustainability. The geographical distribution of B Corp and ISO certifications is not homogeneous, with North America and Anglo Saxons countries clearly leading in the number of B Corp certificates. Nevertheless, B Corps have been growing in other regions such as Europe. Moreover, B Corps companies differ from the mainstream ISO 9001 
and ISO 14001 certified ones, being of smaller size, mostly from the service sector, with a stronger emphasis on Workers and Community rather than customers. The results indicate that ISO 14001 certified B Corps have higher scores in the environment dimension, suggesting consistency between both approaches (RQ2). However, concerning the other B Corp variables distributions, the research results suggest the need for a more substantial alignment between B Corp and ISO 9001/14001, which can be considered as an input for the ongoing B Lab process review on the performance requirements for $B$ Corp certification (B Corporation, 2021b), that is expected to further clarify certification requirements, emphasizing continuous improvement and social and environmental performance. Hence, the present research contributes to bridging the B Corp and ISO 9001/14001 standards worlds at a theoretical and managerial level, aiming for an integrated and synergistic organizational approach that can promote SD and CSR. The many thousands of ISO 9001 and ISO 14001 certified organizations worldwide can adopt and certify with B Corp, further enhancing their economic, environmental, and social performance. On the other hand, the B Corp movement and the B Corp certified organizations can also benefit from the ISO 9001/14001 International Standards experience.

\subsection{Limitations and future research work}

Although addressing all available data this research should be reinforced through a larger and more balanced sample size of ISO 9001 and ISO 14001 certified B Corps. B Corp certification (with a minimum of 80 BIA points) does not unveil possible unbalances between the five BIA dimensions which might raise potential consistency issues. Future studies should replicate this research with a bigger sample data and take into consideration the identified control variables such as size, sector, and location.

\section{ACKNOWLEDGMENTS}

Vanda Lima gratefully acknowledge financial support from FCT-Fundação para a Ciência e Tecnologia (Portugal), national funding through project UIDB/04728/2020.

\section{ORCID}

Luis Fonseca (D) https://orcid.org/0000-0001-5668-0656 José Carlos Sá (D) https://orcid.org/0000-0002-2228-5348 Vanda Lima (D) https://orcid.org/0000-0001-9242-7092 Gilberto Santos (D) https://orcid.org/0000-0001-9268-3272 Rui Silva (D) https://orcid.org/0000-0002-7929-0367

\section{REFERENCES}

Adams, C. A. (2017). Conceptualising the contemporary corporate value creation process. Accounting, Auditing \& Accountability Journal, 30(4), 906-931.

Araújo, R., Santos, G., da Costa, J. B., \& Sá, J. C. (2019). The quality management system as a driver of organizational culture: An empirical study in the Portuguese textile industry. Quality Innovation Prosperity, 23(1), 1-24.
Aupperle, K., Carroll, A., \& Hatfield, J. (1985). An empirical examination of the relationship between corporate social responsibility and profitability. Academy of Management Journal, 28(2), 446-463.

B Corporation (2021a). Available: https://bcorporation.net/ (accessed 17 June 2021).

B Corporation (2021b). Available: https://bcorporation.net/news/ performance-requirements-review-update-survey-results-and-nextsteps (accessed 17 June 2021).

B Lab Certification. Available: https://bcorporation.net/certification (accessed 4 March 2021).

B Lab Certification Requirements. Available: https://bcorporation.net/ certification/meet-therequirements (accessed 4 March 2021).

Barbosa, L. C. F. M., de Oliveira, O. J., \& Santos, G. (2018). Proposition for the alignment of the integrated management system (quality, environmental and safety) with the business strategy. International Journal for Quality Research, 12(4), 925-940.

Barney, J. (1991). Firm resources and sustained competitive advantage. Journal of Management, 17(1), 99-120.

Barney, J. B. (2001). Resource-based theories of competitive advantage: A ten-year retrospective on the resource-based view. Journal of Management, 27(6), 643-650.

Berg, B. L. (2009). An Introduction to Content Analysis. Qualitative Research Methods for Social Sciences (7th ed., pp. 338-377). Allyn \& Bacon.

Bernardo, M., Alexandra, S., Tarí, J. J., \& Molina-Azorín, J. F. (2015). Benefits of management systems integration: A literature review. Journal of Cleaner Production, 94, 260-267.

Berrone, P., Surroca, J., \& Tribó, J. A. (2007). Corporate ethical identity as a determinant of firm performance: $A$ test of the mediating role of stakeholder satisfaction. Journal of Business Ethics, 76(1), 35-53.

BIA (2021) Available: https://kb.bimpactassessment.net/en/support/ solutions/articles/43000547789-overview-of-changes-in-v6-of-thebias, accessed 27 May 2021.

Boiral, O. (2012). ISO 9000 and organizational effectiveness: A systematic review. Quality Management Journal, 19, 16-37.

Bravi, L., Murmura, F., \& Santos, G. (2019). The ISO 9001:2015 quality management system standard: Companies' drivers, benefits and barriers to its implementation. Quality Innovation Prosperity, 23(2), 64-82.

Bravi, L., Santos, G., Pagano, A., \& Murmura, F. (2020). Environmental management system according to ISO 14001:2015 as a driver to sustainable development. Corporate Social Responsibility and Environmental Management, 27(6), 2599-2614.

Büthe, T., \& Mattli, W. (2011). The New Global Rulers: The Privatization of Regulation in the World Economy. Princeton University Press.

Carroll, A. (1991). The pyramid of corporate social responsibility: Towards the moral management of organizational stakeholders. Business Horizons, 34, 39-48.

Carroll, A. (1999). Corporate social responsibility: Evolution of a definitional construct. Business and Society, 38, 268-295.

Carroll, A. B., \& Schwartz, M. S. (2003). Corporate social responsibility: A three-domain approach. Business Ethics Quarterly, 13(4), 503-530.

Carroll, A. B., \& Shabana, K. M. (2010). The business case for corporate social responsibility: A review of concepts, research and practice. International Journal of Management Reviews, 12, 85-105.

Carvalho, F., Santos, G., \& Gonçalves, J. (2020). Critical analysis of information about integrated management systems and environmental policy on the Portuguese firms' website, towards sustainable development. Corporate Social Responsibility and Environmental Management, 27(2), 1069-1088.

Certified B Corp. The complete guide to B Corp certification for small to medium-sized enterprises join the global movement of people using business as a force for good. 2020. Available: https://static1. squarespace.com/static/5b1a6e5daa49a1ac7a0b7513/t/5d2c3d0c9d 58c40001d3b404/1563180310751/Complete_Guide_to_B_Corp_ Certification_for_SME.pdf (accessed 26 May 2021). 
Chatzoglou, P., Chatzoudes, D., \& Kipraios, N. (2015). The impact of ISO 9000 certification on firms' financial performance. International Journal of Operations \& Production Management, 35, 145-174.

Chen, X., \& Kelly, T. F. (2015). B-corps-A growing form of social Enterprise. Journal of Leadership and Organizational Studies, 22, 102-114.

Costa, A. R., Barbosa, C., Santos, G., \& Alves, M. R. (2019). Six sigma: Main metrics and $\mathrm{R}$ based software for training purposes and practical industrial quality control. Quality Innovation Prosperity Journal, 23(2), 83-100.

Dahlsrud, A. (2008). How corporate social responsibility is defined: An analysis of 37 definitions. Corporate Social Responsibility and Environmental Management, 15(1), 1-13.

Davis, K. (1973). The case for and against business assumption of social responsibilities. Academy of Management Journal, 16(2), 312-322.

Diez-Busto, E., Sanchez-Ruiz, L., \& Fernandez-Laviada, A. (2021). The B Corp movement: A systematic literature review. Sustainability, 13, 2508.

DiMaggio, P. J., Powell, W. W. (2000). The iron cage revisited institutional isomorphism and collective rationality in organizational fields, Economics meets Sociology in strategic management. Emerald Group Publishing Limited.

Directory of Certified B Corporation (2021). Available: https:// bcorporation.net/directory (accessed April 2021).

Dobers, P., \& Springett, D. (2010). Corporate social responsibility: Discourse, narratives and communication. Corporate Social Responsibility and Environmental Management, 17, 63-69.

Eells, R. (1958). Corporate giving: Theory and policy. California Management Review, 1, 37-46.

Fonseca, L. (2021). The EFQM 2020 model. A theoretical and critical review. Total Quality Management \& Business Excellence, 1-28. https:// doi.org/10.1080/14783363.2021.1915121

Fonseca, L., \& Carvalho, F. (2019a). The reporting of SDGs by quality, environmental, and occupational health and safety-certified organizations. Sustainability, 11, 5797.

Fonseca, L., \& Carvalho, F. (2019b). The reporting of SDGs by quality, environmental, and occupational health and safety-certified organizations. Sustainability, 11, 5797.

Fonseca, L., \& Ferro, R. (2016). Does it pay to be social responsible? Portuguese SMEs feedback. Intangible Capital, 12(2), 487-505.

Fonseca, L., Ramos, A., Rosa, A., Braga, A. C., \& Sampaio, P. (2016). Stakeholders satisfaction and sustainable success. International Journal of Industrial and Systems Engineering, 24(2), 144-157.

Fonseca, L. C. M., Domingues, J. P., Machado, P. B., \& Harder, D. (2019). ISO 9001:2015 adoption: A multi-country empirical research. Journal Industrial Engineering and Management, 12, 27-50.

Fonseca, L. M. (2015a). Strategic drivers for implementing sustainability programs in Portuguese organizations-Let's listen to Aristotle: From triple to quadruple bottom line. Sustainability: The Journal of Record, 8(3), 136-142.

Fonseca, L. M., \& Domingues, J. P. (2018). Exploratory research of ISO 14001:2015 transition among Portuguese organizations. Sustainability, 10, 781.

Fonseca, L. M., Domingues, J. P., \& Dima, A. M. (2020). Mapping the sustainable development goals relationships. Sustainability, 12, 3359

Fonseca, L. M., Domingues, J. P., Machado, P. B., \& Calderón, M. (2017) Management system certification benefits: Where do we stand? Journal Industrial Engineering and Management, 10, 476-494.

Fonseca, L. M. C. M. (2015b). ISO 14001:2015 an improved tool for sustainability. Journal Industrial Engineering and Management, 8, 37-50.

Freeman, R. E. (1984). Strategic Management: A Stakeholder Approach. Pitman.

Freeman, R. E., \& Dmytriyev, S. (2017). Corporate social responsibility and stakeholder theory: Learning from each other. Symphonya: Emerging Issues in Management, 1, 7-15.
Gamble, E. N., Parker, S. C., \& Moroz, P. W. (2019). Measuring the integration of social and environmental missions in hybrid organizations. Journal of Business Ethics, 167, 271-284.

Gazzola, P., Grechi, D., Ossola, P., \& Pavione, E. (2019). Certified benefit corporations as a new way to make sustainable business: The Italian example. Corporate Social Responsibility and Environmental Management, 26(6), 1435-1445.

Gianni, M., Gotzamani, K., \& Tsiotras, G. (2017). Multiple perspectives on integrated management systems and corporate sustainability performance. Journal of Cleaner Production, 168, 1297-1311.

ISO. (2010). ISO 26000:2010 International Standard, Guidance on Social Responsibility. International Organization for Standardization.

ISO. (2015a). International Organization for Standardization. ISO 9001:2015. Quality Management Systems-Requirements. International Organization for Standardization.

ISO. (2015b). International Organization for Standardization. ISO 14001: 2015. Environmental Management System: Requirements with Guidance for Use. International Organization for Standardization.

ISO (2020). The ISO survey. Available: https://isotc.iso.org/livelink/ livelink?func=\|\&objld=18808772\&objAction=browse\&viewType =1 (accessed 4 March 2021).

Izzo, M. F., Ciaburri, M., \& Tiscini, R. (2020). The challenge of sustainable development goal reporting: The first evidence from Italian listed companies. Sustainability, 12, 3494.

Johnson, H. L. (1971). Business in Contemporary Society: Framework and Issues. Wadsworth Pub. Co.

Kim, S., Karlesky, M. J., Myers, C. G., \& Schifeling, T. (2016). Social responsibility: Why companies are becoming B corporations. Harvard Business Review, 17, 2-5.

Kim, Y. (2021). Certified corporate social responsibility? The current state of certified and decertified B corps. Corporate Social Responsibility and Environmental Management, 1, 1-9.

Kirst, R. W., Borchardt, M., Carvalho, M. N. M., \& Pereira, G. M. (2021). Best of the world or better for the world? A systematic literature review on benefit corporations and certified B corporations contribution to sustainable development. Corporate Social Responsibility and Environmental Management, 1-18. https://doi.org/10.1002/csr. 2160

Lankoski, L. (2016). Alternative conceptions of sustainability in a business context. Journal of Cleaner Production, 139, 847-857.

Lee, S. M., Noh, Y., Choi, D., \& Rha, J. S. (2017). Environmental policy performances for sustainable development: From the perspective of ISO 14001 certification. Corporate Social Responsibility and Environmental Management, 24(2), 108-120.

Ma, Y., Liu, Y., Appolloni, A., \& Liu, J. (2021). Does green public procurement encourage firm's environmental certification practice? The mediation role of top management support. Corporate Social Responsibility and Environmental Management, 28(3), 1002-1017.

Margolis, J. D., \& Walsh, J. P. (2003). Misery loves companies: Rethinking social initiatives by business. Administrative Science Quarterly, 48(2), 268-305.

Mattingly, J. E. (2017). Corporate social performance A review of empirical research examining the corporation-society relationship using kinder, Lydenberg, Domini social ratings data. Business \& Society, 56(6), 796-839.

Mcguire, J., Sundgren, A., \& Schneeweis, T. (1988). Corporate social responsibility and firm financial performance. Academy of Management Journal, 31(4), 854-872.

Mcwilliams, A., \& Siegel, D. (2001). Corporate social responsibility: A theory of the firm perspective. The Academy of Management Review, 26(1), 117-127.

Mcwilliams, A., \& Siegel, D. (2011). Creating and capturing private and social value: Strategic corporate social responsibility, resource based theory and sustainable competitive advantage. Journal of Management, 37(5), 1480-1495. 
Meyer, J. W., \& Rowan, B. (1977). Institutionalized organizations: Formal structure as myth and ceremony. American Journal of Sociology, 83(2), 340-363.

Murillo-Avalos, C. L., Cubilla-Montilla, M., Sánchez, M. A. C., \& VicenteGalindo, P. (2021). What environmental social responsibility practices do large companies manage for sustainable development? Corporate Social Responsibility and Environmental Management, 28(1), 153-168.

Murmura, F., Liberatore, L., Bravi, L., \& Casolani, N. (2018). Evaluation of Italian Companies' perception about ISO 14001 and eco management and audit scheme III: Motivations, benefits and barriers. Journal of Cleaner Production, 174, 691-700.

Nunhes, T. V., \& Oliveira, O. J. (2018). Analysis of integrated management systems research: Identifying core themes and trends for future studies. Total Quality Management and Business Excellence, 31, 1243-1265.

Orlitzky, M., Schmidt, F. L., \& Rynes, S. L. (2003). Corporate social and financial performance: A meta-analysis. Organisation Studies, 24(3), 403-441.

Paelman, V., Van Cauwenberge, P., \& Bauwhede, H. V. (2020). Effect of B Corp certification on short-term growth: European evidence. Sustainability, 12, 8459.

Poddar, A., Narula, S. A., \& Zutshi, A. (2019). A study of corporate social responsibility practices of the top Bombay stock exchange 500 companies in India and their alignment with the sustainable development goals. Corporate Social Responsibility and Environmental Management, 26(6), 1184-1205.

Poksinska, B., Eklund, J., Jörn, D., \& Jens, J. (2006). ISO 9001:2000 in small organizations. International Journal of Quality and Reliability Management, 23, 490-512.

Prajogo, D. I. (2011). The roles of firms' motives in affecting the outcomes of ISO 9000 adoption. International Journal of Operations \& Production Management, 31, 78-100.

Rankin, C. P., \& Matthews, T. L. (2020). Patterns of B corps certification: The role of institutional, economic, and political resources. Societies, 10, 72.

Rebelo, M., Santos, G., \& Silva, R. (2015). Integration of standardized management systems: A dilemma? System, 3, 45-59.

Ritter, T., \& Lettl, C. (2018). The wider implications of business-model research. Long Range Planning, 51(1), 1-8.

Romi, A., Cook, K. A., \& Dixon-Fowler, H. R. (2018). The influence of social responsibility on employee productivity and sales growth: Evidence from certified B corps. Sustainability Accounting, Management and Policy Journal, 9, 392-421.

Sá, J. C., Vaz, S., Carvalho, O., Lima, V., Morgado, L., Fonseca, L., Doiro, M., \& Santos, G. (2020). A model of integration ISO 9001 with lean six sigma and main benefits achieved. Total Quality Management and Business Excellence, 1-25. https://doi.org/10.1080/14783363. 2020.1829969

Santos, G., Gomes, S., Braga, V., Braga, A., Lima, V., Teixeira, P., \& Sá, J. C. (2019). Value creation through quality and innovation - A case study on Portugal. TQM Journal, 31(6), 928-947.

Santos, G., Mandado, E., Silva, R., \& Doiro, M. (2019). Engineering learning objectives and computer assisted tools. European Journal of Engineering Education, 44(4), 616-628.

Santos, G., Mendes, F., \& Barbosa, J. (2011). Certification and integration of management systems: The experience of Portuguese small and medium enterprises. Journal of Cleaner Production, 19(17-18), 19651974.

Santos, G., Murmura, F., \& Bravi, L. (2018). SA 8000 as a tool for a sustainable development strategy. Corporate Social Responsibility and Environmental Management, 25(1), 95-105.

Santos, G., Rebelo, M., Barros, S., Silva, R., Pereira, M., Ramos, G., \& Lopes, N. (2014). Developments regarding the integration of the occupational safety and health with quality and environment management systems (2014) chapter of the book. In I. Kavouras \& M.-C. G. Chalbot
(Eds.), Occupational Safety and Health - Public Health in the 21st Century (pp. 113-146). The Nova Science Publishers.

Santos, G., Sá, J. C., Félix, M. J., Barreto, L., Carvalho, F., Doiro, M., Zgodavová, K., \& Stefanović, M. (2021). New needed quality management skills for quality managers 4.0. Sustainability (Switzerland), 13(11), 6149.

Sfreddo, L. S., Vieira, G. B. B., Vidor, G., \& Santos, C. H. S. (2021). ISO 9001 based quality management systems and organisational performance: A systematic literature review. Total Quality Management \& Business Excellence, 32(3-4), 389-409.

Silvestre, W. J., \& Fonseca, A. (2020). Integrative sustainable intelligence: A holistic model to integrate corporate sustainability strategies. Corporate Social Responsibility and Environmental Management, 27, 1578-1590.

Singh, P. J. (2008). Empirical assessment of ISO 9000 related management practices and performance relationships. International Journal of Production Economics, 113, 40-59.

Siva, V., Gremyr, I., Bergquist, B., Garvare, R., Zobel, T., \& Isaksson, R. (2016). The support of quality management to sustainable development: A literature review. Journal of Cleaner Production, 138, 148-157.

Talapatra, S., Santos, G., Uddin, K., \& Carvalho, F. (2019). Main benefits of integrated management systems through literature review. International Journal of Quality Research, 13(4), 1037-1054.

Tarí, J. J., Molina-Azorín, J. F., \& Heras, I. (2012). Benefits of the ISO 9001 and ISO 14001 standards: A literature review. Journal Industrial Engineering and Management, 5, 297-322.

Trudel, R., \& Cotte, J. (2009). Does being ethical pay? MIT Sloan Management Review, 50(2), 61-68.

United Nations. Agenda for Development; UN: New York, NY, 1997.

United Nations (2012). Available: https://sustainabledevelopment.un.org/ rio20 (accessed 19 November 2019).

United Nations. (2015). Transforming Our World: The 2020 agenda for Sustainable Development. New York, NY.

United Nations Brundtland Report. (1987). Report of the world commission on environment and development: Our common future. Available: http://www.undocuments.net/our-common-future.pdf (accessed on 19 November 2019).

Van Zanten, J. A., \& Van Tulder, R. (2018). Multinational enterprises and the sustainable development goals: An institutional approach to corporate engagement. Journal of International Business Policy, 1, 208-233.

Villela, M., Bulgacov, S., \& Morgan, G. (2021). B Corp certification and its impact on organizations over time. Journal of Business Ethics, 170, 343-357.

Yahya, S., \& Goh, W. K. (2001). The implementation of an ISO 9000 quality system. International Journal Quality and Reliability Management, 18, 941-966.

Zeng, S. X., Tam, C. M., Tam, V. W. Y., \& Deng, Z. M. (2005). Towards implementation of ISO 14001 environmental management systems in selected industries in China. Journal of Cleaner Production, 13, 645-656.

Zenisek, T. J. (1979). Corporate social responsibility: A conceptualization based on organizational literature. Academy of Management Review, 4, 359-368.

How to cite this article: Fonseca, L., Silva, V., Sá, J. C., Lima, V., Santos, G., \& Silva, R. (2021). B Corp versus ISO 9001 and 14001 certifications: Aligned, or alternative paths, towards sustainable development? Corporate Social Responsibility and Environmental Management, 1-13. https://doi.org/10.1002/ csr.2214 